\title{
Identification and Preliminary SAR Studies of (+)-Geodin as a Glucose Uptake Stimulator for Rat Adipocytes
}

\author{
Seiichi Sato, Noriyuki Okusa, Akiyo Ogawa, Takao Ikenoue, Tetsuya Seki, \\ Takashi Tsuji
}

Received July 19, 2005 / Accepted September 12, 2005

(C) Japan Antibiotics Research Association

\begin{abstract}
Geodin (1) was isolated from Penicillium glabrum AJ117540 with activity that stimulates glucose uptake by rat adipocytes. Unlike insulin it is active in the presence of wortmannin. Dihydrogeodin (2) and sulochrin (3) which are the precursors of $(+)$-geodin biosynthesis were also isolated from the same fungus. Preliminary SAR studies of 1 showed some analogues had enhanced activity. Especially, the activities of racemic geodin and dibromo analogue (7a) were comparable to that of the natural product.
\end{abstract}

Keywords (+)-geodin, glucose uptake stimulator, adipocytes

\section{Introduction}

Insulin is a hormone, which regulates carbohydrate and lipid metabolisms, protein synthesis, and cell growth. The pathogenesis of type 2, non-insulin dependent diabetes mellitus (NIDDM) is complex, and not completely understood as yet, but appears to be the consequence of a combination of defective insulin production and secretion, and insulin resistance in peripheral target tissues [1]. Most of the drugs are insulin secretagogues or insulin sensitizers and their long term use causes resistance. Therefore, orally bioavailable small molecules which mimic insulin action are needed. In our search for novel antidiabetic agents with insulin-like effect, we screened over 6500 samples of natural product extracts for their ability to enhance glucose uptake activity on isolated rat adipocytes as an index. (+)-
Geodin (1), a known fungal metabolite, was isolated from Penicillium glabrum AJ117540 as an active substance (Fig. 1). Dihydrogeodin (2) and sulochrin (3), the precursors of 1, were also isolated from the same fungal extract. In this study, preliminary mechanistic insight and SAR are reported.

\section{Results and Discussion}

\section{Isolation and Identification of (+)-Geodin (1),}

Dihydrogeodin (2), and Sulochrin (3)

The fermentation broth was centrifuged to obtain mycelium, which was then extracted with acetone. The acetone extract was partitioned between $\mathrm{CHCl}_{3}$ and $40 \%$ aqueous $\mathrm{MeOH}$. The $\mathrm{CHCl}_{3}$ extracts were combined and chromatographed on silica gel column with mixture of $\mathrm{CHCl}_{3}$ and $\mathrm{MeOH}$ containing $1 \%$ formic acid. Further purification was achieved by a preparative HPLC using an ODS column to give $\mathbf{1}$ as an active compound. 1 was previously isolated as a fugal metabolite with antibacterial activity [2] but its activity on glucose metabolism has been not reported so far. The related compound $\mathbf{2}$ and $\mathbf{3}$ were also isolated from same extract but they were devoid of glucose uptake stimulatory activity (Scheme 1).

Compound 1 was obtained as a yellow solid. Negative ESI mass spectrum provided a molecular ion at $\mathrm{m} / \mathrm{z} 397$ $(\mathrm{M}-\mathrm{H})^{-}$. Analyses of various NMR spectral data deduced that 1 was $(+)$-geodin. Finally, 1 was identified as $(+)$ geodin by comparison with an authentic specimen $[3,4]$. Compound $\mathbf{2}$ was obtained as a yellow solid, and $\mathbf{3}$ was as a
S. Sato (Corresponding author), N. Okusa, A. Ogawa, T. Ikenoue, T. Seki, T. Tsuji: Pharmaceutical Research
Laboratories, Ajinomoto Co., Inc., 1-1 Suzuki-cho, Kawasaki 210-8681, Japan, E-mail: seiichi_sato@ajinomoto.com 
Penicillium glabrum AJ117540(10 liters)

Acetone extract of mycelium

Partitioned between $\mathrm{CHCl}_{3}$ and $40 \%$ aqueous $\mathrm{MeOH}$

$\mathrm{CHCl}_{3}$

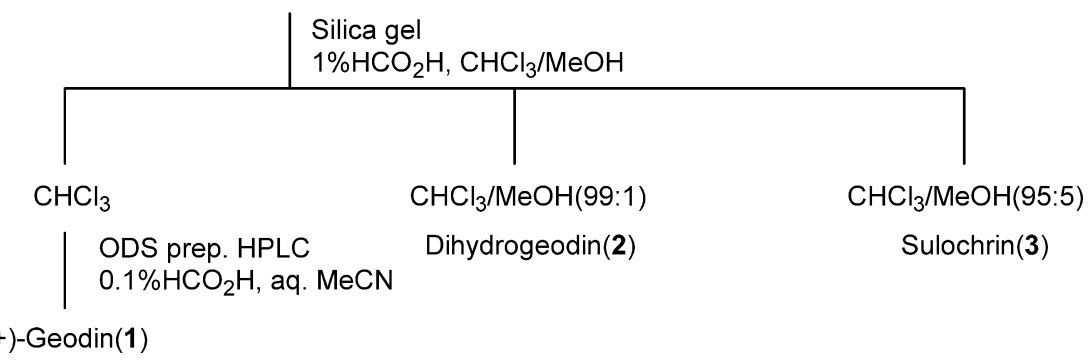

$(+)$-Geodin(1)

Scheme 1 Isolation procedure for (+)-geodin (1), dihydrogeodin (2), and sulochrin (3<smiles>COC1=CC(=O)C=C(OC)C12Oc1c(Cl)c(C)c(Cl)c(O)c1C2=O</smiles>

(+)-geodin (1)<smiles>[R]c1cc(C(=O)c2c(O)cc(O)cc2C(C)=O)c(O)c([R])c1C</smiles>

dihydrogeodin (2) $\mathrm{R}=\mathrm{Cl}$ sulochrin (3) $\mathrm{R}=\mathrm{H}$

Fig. 1 Structures of (+)-geodin (1), dihydrogeodin (2), and sulochrin (3).

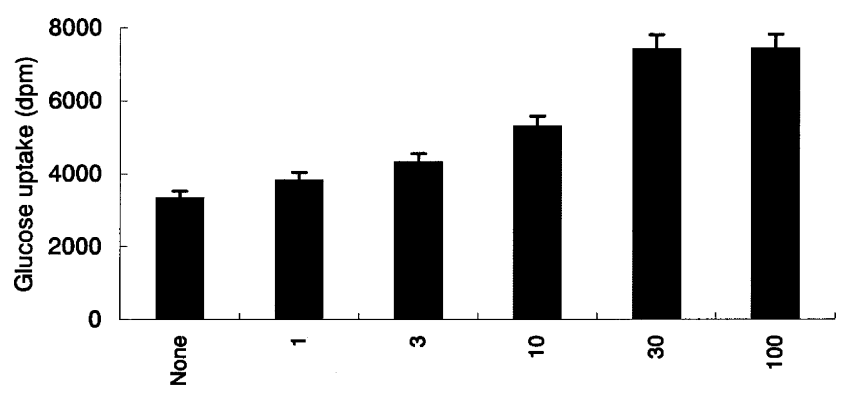

(+)-Geodin dose $(\mu \mathrm{g} / \mathrm{mL})$

Fig. $2(+)$-Geodin-stimulated 2-deoxyglucose uptake by rat adipocytes.

Rat adipocytes were incubated for 30 minutes with various concentration of $(+)$-geodin. The cellular glucose uptake during further 5 minutes incubation with the addition of 2-deoxyglucose was determined.

white solid, respectively. The UV and ${ }^{1} \mathrm{H}$ NMR spectral data of $\mathbf{2}$ were good agreement with those of dihydrogeodin [4]. Therefore 2 was identified as dihydrogeodin. 3 was identified as sulochrin by comparison of the ${ }^{1} \mathrm{H}$ NMR and MS data with those of 2 (Fig. 1).

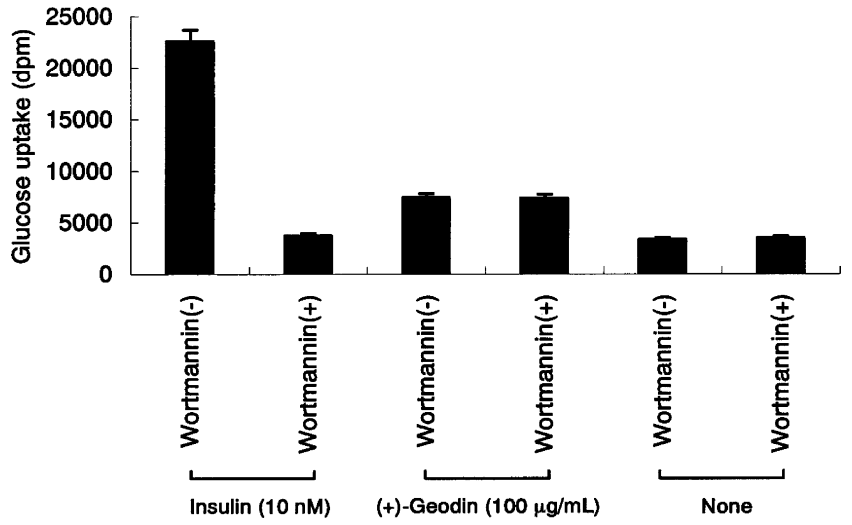

Fig. 3 Effect of wortmannin on insulin and (+)-geodinstimulated 2-deoxyglucose uptake by rat adipocytes.

Rat adipocytes were incubated for 30 minutes with $100 \mu \mathrm{g} / \mathrm{ml}$ of $(+)$-geodin with or without $0.1 \mu \mathrm{M}$ of wortmannin. The cellular glucose uptake during further 5 minutes incubation with the addition of 2-deoxyglucose was determined.

\section{Glucose Uptake Activity}

$(+)$-Geodin showed stimulation of glucose uptake by rat adipocytes in a dose dependent manner in vitro. Under the same conditions, $10 \mathrm{nM}$ of insulin stimulated glucose uptake by $673 \%$ of that of basal uptake (Fig. 2). Zhang et al. reported that a small insulin mimetic, L-783,281 was isolated from a fungal extract of Pseudomassaria sp. It is a selective insulin receptor tyrosine kinase activator, and stimulates PI 3-kinase activation and phosphorylation of Akt kinase [5]. Insulin-stimulated glucose uptake was antagonized by $0.1 \mu \mathrm{M}$ of wortmannin which is specific inhibitor of PI 3-kinase [6,7], however, the activity of $\mathbf{1}$ was not reduced (Fig. 3). Thus, it was deduced that (+)-geodin stimulates glucose uptake into cells by a different mechanism from those of insulin and L-783,281. 


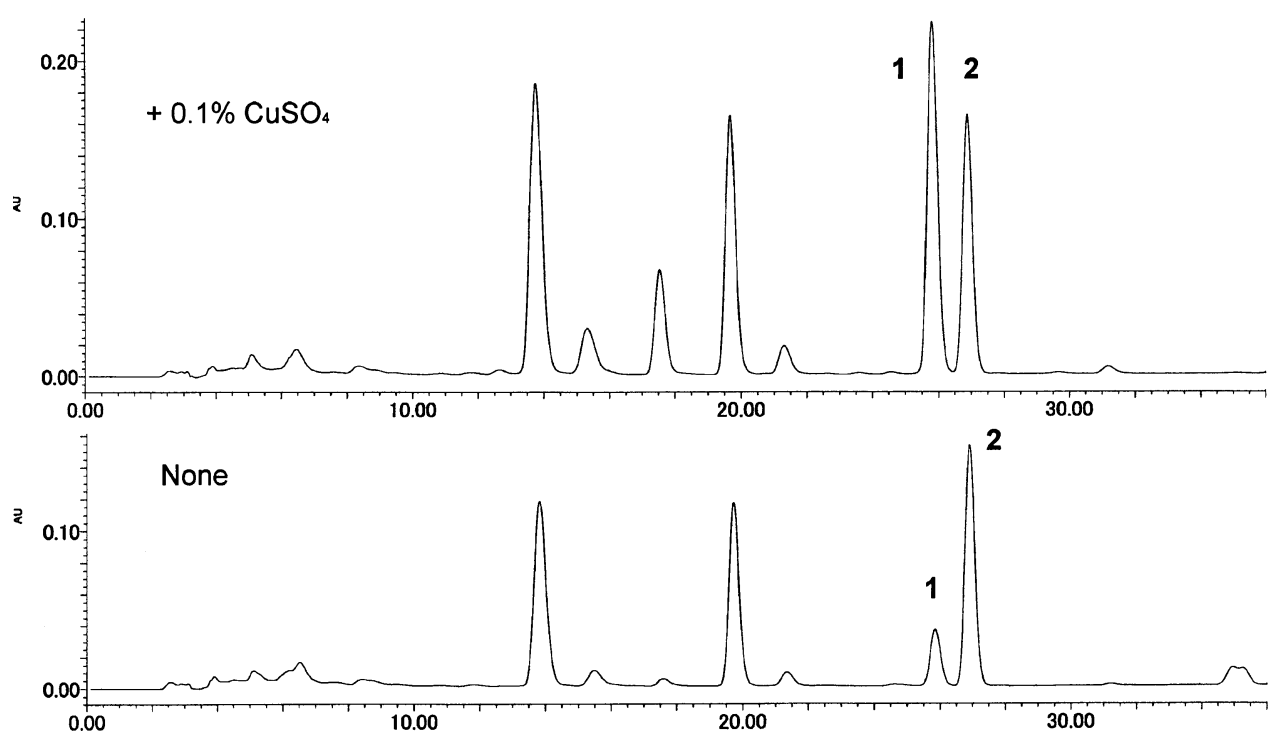

Fig. 4 HPLC chromatograms of the acetone extract of Penicillium glabrum AJ117540.

Penicillium glabrum AJ117540 was fermented in the producing medium with or without $\mathrm{CuSO}_{4}$. HPLC was carried out on a column (Inertsil ODS-3, 0.6 i.d. $\times 15 \mathrm{~cm}$ ) with linear gradient from $40 \%$ to $70 \%$ aqueous $\mathrm{MeCN}$ at a flow rate of $1.0 \mathrm{ml} / \mathrm{minute}$.

\section{Conversion of Dihydrogeodin to Racemic Geodin}

The stimulating activity of glucose uptake of $\mathbf{1}$ prompted us to evaluate its activity in vivo and synthesize its analogues. However, the production of $1(5 \sim 10 \mathrm{mg} /$ liter $)$ was not enough for derivatization and pharmacological tests in vivo. Further investigation revealed that mycelium extract of producing strain contained large quantities of dihydrogeodin (2), a biosynthetic precursor of (+)-geodin. Oxidation of 2 with DDQ gave 54\% yield of racemic geodin [4], which was identical to $\mathbf{1}$ with respect to ${ }^{1} \mathrm{H}$ NMR spectrum and chromatographic behavior on ODS HPLC. The activity of racemic $\mathbf{1}$ was comparable to that of the (+)-isomer.

\section{Fermentation of AJ117540 Strain with $\mathrm{CuSO}_{4}$}

Sankawa et al. reported that Aspergillus terreus dihydrogeodin oxidase, enzyme which catalyzes the intramolecular stereospecific phenol oxidative coupling reaction, namely, converting dihydrogeodin to $(+)$-geodin, was a multicopper enzyme [3]. Fermentation of the producing strain in the medium containing $\mathrm{CuSO}_{4}$ resulted in improving productivity of (+)-geodin (up to $54 \mathrm{mg} /$ liter) (Fig. 4). The amount of $(+)$-geodin reached the maximum after 3 days of growth without $\mathrm{Cu}^{2+}$, however, addition of $\mathrm{CuSO}_{4}$ at this stage show little improvement in productivity (data not shown). These results indicated that the $P$. glabrum dihydrogeodin oxidase is also a copper enzyme.<smiles>COC1=CC(=O)C=C(C)C12Oc1c(Cl)c(C)c(Cl)c(O)c1C2=O</smiles>

$( \pm)$-Geodin<smiles>COC1=CC(=O)C=C(C(=O)O)C12Oc1c(Cl)c(C)c(Cl)c(O)c1C2=O</smiles>

$( \pm)-4$ a) $n-\mathrm{Bu}_{4} \mathrm{NOH}, \mathrm{THF}, 60^{\circ} \mathrm{C}$

Scheme 2

\section{Synthesis and Glucose Uptake Activity of Geodin Analogues}

A series of geodin analogues were synthesized to evaluate stimulating activity of glucose uptake of related compounds. Since the stereochemistry of the spiro carbon is not important for the activity, SAR was studied with racemic derivatives. Treatment of $( \pm)$-geodin with tetra- $n$ butylammonium hydroxide [8] resulted in hydrolysis to give the carboxylic acid analogue erdin (4) (Scheme 2). The phenolic hydroxyl group of ( \pm )-geodin was alkylated to afford various ether derivatives including methyl (5a), benzyl (5b), tert-butoxycarbonylmethyl (5c), and carboxymethyl ether (5d). The synthesis of methyl ether $\mathbf{5 a}$ is outlined in Scheme 3. ( \pm )-Geodin was reacted with methyl iodide in the presence of $\mathrm{K}_{2} \mathrm{CO}_{3}$ in DMF to give methyl ether derivative $\mathbf{5 a}$. $\mathbf{5 b} \sim \mathbf{d}$ were also prepared in a similar method (Fig. 5). The derivatives 7 with bromine and 
iodine atom in place of chlorine atom on benzene ring were also synthesized. Sulochrin (3) isolated from the same fungus was brominated with benzyltrimethylammonium tribromide to obtain $\mathbf{6}$, which was converted to $7 \mathbf{a}$ by oxidation with DDQ. Iodinated analogue $\mathbf{7 b}$ was prepared from 3 by treatment with iodine/potassium iodide (Scheme 4).

Stimulation of glucose uptake in rat adipocytes by the<smiles>COC(=O)C1=CC(=O)C=C(OC)C12Oc1c(Cl)c(C)c(Cl)c(O)c1C2=O</smiles><smiles>C1CC1</smiles>

$( \pm)$-Geodin geodin analogues at a dose of $30 \mu \mathrm{g} / \mathrm{ml}$ are shown in Table 1.

The ether derivatives except for $\mathbf{5} \mathbf{d}$, and bromine or iodine substituted analogues retained activity, however, the activity of the ethers became weak dependent on the size of substituent. In contrast, more polar compounds $\mathbf{4}$ and $\mathbf{5 d}$ were inactive. It is demonstrated that phenolic hydroxyl group is not necessary to exhibit desired activity. Inactive compounds may have low affinity for the target molecule or low permeability into cells. Under the assay conditions, geodin and its analogues did not show cytotoxic activity. Evaluation of the glucose uptake mechanism and pharmacological study in vivo, and further synthesis of analogues are in progress.

a) Mel, $\mathrm{K}_{2} \mathrm{CO}_{3}, \mathrm{DMF}$, rt

Scheme 3<smiles>[R]Oc1c(Cl)c(C)c(Cl)c2c1C(=O)C1(O2)C(OC)=CC(=O)C=C1C(C)=O</smiles>

$( \pm)-5 a \mathrm{R}=\mathrm{Me}$

$( \pm)-5 b \mathrm{R}=\mathrm{Bn}$

$( \pm)-5 \mathrm{c} \mathrm{R}=\mathrm{CH}_{2} \mathrm{CO}_{2} t-\mathrm{Bu}$

$( \pm)-5 d \mathrm{R}=\mathrm{CH}_{2} \mathrm{CO}_{2} \mathrm{H}$

Table 1 Various geodin analogues stimulated glucose uptake at a dose of $30 \mu \mathrm{g} / \mathrm{ml}$

\begin{tabular}{cc}
\hline Compound & 2-[ $\left.{ }^{14} \mathrm{C}\right]$-deoxyglucose uptake $(\mathrm{T} / \mathrm{C})^{\mathrm{a}}$ \\
\hline$( \pm)-\mathbf{4}$ & 1.09 \\
$( \pm)-\mathbf{5 a}$ & 1.83 \\
$( \pm)-\mathbf{5 b}$ & 1.62 \\
$( \pm)-\mathbf{5} \mathbf{c}$ & 1.38 \\
$( \pm)-\mathbf{5 d}$ & 1.08 \\
$( \pm)-\mathbf{7 a}$ & 3.07 \\
$( \pm)-\mathbf{7 b}$ & 2.07 \\
$( \pm)-\mathbf{1}$ & 2.44 \\
\hline
\end{tabular}

Fig. 5 Structures of racemic geodin analogues.<smiles>COc1cc(O)cc(C(C)=O)c1C(=O)c1c(O)cc(C)cc1O</smiles>

3<smiles>C1CCC1</smiles><smiles>COC(=O)C1=CC(=O)C=C(OC)C12Oc1c(I)c(C)c(I)c(O)c1C2=O</smiles>

$( \pm)-7 b$<smiles>C1CCCCC1</smiles><smiles>COc1cc(O)cc(C(C)=O)c1C(=O)c1c(O)c(Br)c(C)c(Br)c1O</smiles>

6<smiles>COC(=O)C12C=CC(=O)C=C1Oc1c(Br)c(C)c(Br)c(O)c1C2=O</smiles>

$( \pm)-7 a$

a) $\mathrm{BnMe}_{3} \mathrm{~N}^{+} \mathrm{Br}_{3}{ }^{-}, \mathrm{CaCO}_{3}, \mathrm{CH}_{2} \mathrm{Cl}_{2} / \mathrm{MeOH}$, rt; b) DDQ, THF/MeOH, rt;

c) $\mathrm{I}_{2}, \mathrm{KI}, \mathrm{NaOAc}, \mathrm{DMF}$, rt

\section{Scheme 4}




\section{Experimental}

\section{General Methods}

${ }^{1} \mathrm{H}$ NMR and ${ }^{13} \mathrm{C}$ NMR spectra were recorded with a Varian XL-300 spectrometer and JEOL JNM A-400 spectrometer. Mass spectra were recorded on JEOL MS700V spectrometer, JEOL JMS-HX110 spectrometer and Thermoelectron TSQ700 spectrometer. Optical rotation was recorded on a JASCO DIP-370. Silica gel column chromatography was carried out on Wakogel C-300. Silica gel TLC was carried out on Merck Silica gel $60 \mathrm{~F}_{254} 13792$ and Silica gel $60 \mathrm{~F}_{254} 13794$, respectively.

\section{Fermentation}

Strain AJ117540 was isolated from a soil sample collected at Okinawa prefecture, Japan. The strain was identified to be Penicillium glabrum by morphological characteristics. A seed medium containing mashed potatoes $2.0 \%$, glucose $0.5 \%$, NZ-Case (Humco) $0.2 \%$, yeast extract (Difco) $0.2 \%$, $\mathrm{NaCl} 0.2 \%$, and $\mathrm{CaCO}_{3} 0.3 \%$ (pH 7.0) was inoculated with a slant culture of strain $\mathrm{AJ} 117540$, and incubated at $25^{\circ} \mathrm{C}$ on a rotary shaker $(180 \mathrm{rpm})$ for 96 hours. The resultant seed culture was transferred to a hundred $500 \mathrm{ml}$ Erlenmeyer flasks containing $100 \mathrm{ml}$ of a producing medium composed of glucose $2.0 \%$, mannitol $2.0 \%$, glycerol $0.5 \%$, corn germ meal $2.0 \%$, EBIOS $1.0 \%$, amino acid mixture for culture media (Ajinomoto) 3.0\%, and $\mathrm{CaCO}_{3}$ 0.4\% (pH 6.8). The fermentation was carried out at $25^{\circ} \mathrm{C}$ on a rotary shaker $(180 \mathrm{rpm})$ for 96 hours.

\section{Fermentation of Producing Strain with $\mathrm{CuSO}_{4}$}

The fungus AJ117540 was fermented in the producing medium described above containing $\mathrm{CuSO}_{4} \cdot 5 \mathrm{H}_{2} \mathrm{O}(0.1 \%)$ in the same condition.

\section{Isolation of (+)-Geodin (1), Dihydrogeodin (2), and Sulochrin (3)}

The fermentation broth (10 liters) was centrifuged at 7000 rpm for 20 minutes to obtain mycelium, which was extracted with acetone (5 liters) at room temperature. The acetone extract was concentrated in vacuo to give a water suspension $(600 \mathrm{ml})$. After addition of $\mathrm{MeOH}(400 \mathrm{ml})$, aqueous $\mathrm{MeOH}$ solution was extracted with $\mathrm{CHCl}_{3}$ $(500 \mathrm{ml} \times 3)$. The $\mathrm{CHCl}_{3}$ fractions were combined and concentrated to dryness. The brown oily residue $(5.0 \mathrm{~g})$ was applied to a silica gel column $(80$ g, 3.0 i.d. $\times 27 \mathrm{~cm})$ eluting with $\mathrm{CHCl}_{3}, \mathrm{CHCl}_{3} / \mathrm{MeOH}(99: 1)$ and $\mathrm{CHCl}_{3} / \mathrm{MeOH}$ $(99: 5)$ containing $1 \%$ formic acid. The fraction eluted with $\mathrm{CHCl}_{3}$ was purified on preparative reversed phase HPLC (column; Inertsil ODS-3, 1.0 i.d. $\times 15 \mathrm{~cm}$ ) with linear gradient from $50 \%$ to $80 \%$ aqueous $\mathrm{MeCN}$ containing $0.1 \%$ formic acid at a rate of $3.0 \mathrm{ml} /$ minute to yield $4 \mathrm{mg}$ of $(+)$-geodin (1) as yellow solid. The fraction eluted with $\mathrm{CHCl}_{3} / \mathrm{MeOH}(99: 1)$ gave $300 \mathrm{mg}$ of dihydrogeodin (2) as yellow solid, and the fraction eluted with $\mathrm{CHCl}_{3} / \mathrm{MeOH}$ $(95: 5)$ gave $650 \mathrm{mg}$ of crude sulochrin (3).

$(+)$-Geodin $(\mathbf{1}):[\alpha]_{\mathrm{D}}^{22}+119^{\circ}(c 0.08$, THF); ESI MS $m / z$ $397(\mathrm{M}-\mathrm{H})^{-} ;{ }^{1} \mathrm{H}$ NMR $\left(400 \mathrm{MHz}, \mathrm{CDCl}_{3}\right) \delta 7.13(1 \mathrm{H}, \mathrm{d}$, $J=1.2 \mathrm{~Hz}), 5.81(1 \mathrm{H}, \mathrm{d}, J=1.2 \mathrm{~Hz}), 3.89(3 \mathrm{H}, \mathrm{s}), 3.69(3 \mathrm{H}$, s), $2.56(3 \mathrm{H}, \mathrm{s}) ;{ }^{13} \mathrm{C}$ NMR $\left(100 \mathrm{MHz}, \mathrm{CDCl}_{3}\right) \delta 193.3$, $185.0,167.9,165.5,163.4,149.4,146.6,137.5,137.0$, 114.7, 109.4, 108.8, 104.4, 84.5, 57.0, 53.1, 18.7.

Dihydrogeodin (2): ESI MS $m / z 399(\mathrm{M}-\mathrm{H})^{-}$; ${ }^{1} \mathrm{H}$ NMR $\left(300 \mathrm{MHz}, \mathrm{DMSO}-d_{6}\right) \delta 11.71(2 \mathrm{H}, \mathrm{br} \mathrm{s}), 10.06(1 \mathrm{H}, \mathrm{br} \mathrm{s})$, $6.92(1 \mathrm{H}, \mathrm{d}, J=2.1 \mathrm{~Hz}), 6.69(1 \mathrm{H}, \mathrm{d}, J=2.1 \mathrm{~Hz}), 3.65(3 \mathrm{H}$, s), $3.64(3 \mathrm{H}, \mathrm{s}), 2.42(3 \mathrm{H}, \mathrm{s})$.

Sulochrin (3): ESI MS $m / z 331(\mathrm{M}-\mathrm{H})^{-} ;{ }^{1} \mathrm{H}$ NMR (300 MHz, DMSO- $\left.d_{6}\right) \delta 11.41(2 \mathrm{H}, \mathrm{br} \mathrm{s}), 9.95(1 \mathrm{H}, \mathrm{br} \mathrm{s}), 6.88$ $(1 \mathrm{H}, \mathrm{d}, J=1.8 \mathrm{~Hz}), 6.65(1 \mathrm{H}, \mathrm{d}, J=1.8 \mathrm{~Hz}), 6.06(2 \mathrm{H}, \mathrm{s})$, $3.62(3 \mathrm{H}, \mathrm{s}), 3.61(3 \mathrm{H}, \mathrm{s}), 2.48(3 \mathrm{H}, \mathrm{t}, J=1.8 \mathrm{~Hz})$.

\section{Conversion of Dihydrogeodin to Racemic Geodin}

DDQ $(105 \mathrm{mg}, 0.46 \mathrm{mmol})$ was added to a solution of dihydrogeodin (107 mg, $0.27 \mathrm{mmol})$ in $\mathrm{CHCl}_{3} / \mathrm{MeOH}(1: 1)$ $(2 \mathrm{ml})$, and stirred for 3.0 hours at room temperature. After concentration, the resulting material was purified silica gel TLC developed with $\mathrm{CHCl}_{3} / \mathrm{MeOH}(97: 3)$ containing $1 \%$ formic acid to give racemic geodin in 54\% yield.

\section{Synthesis of Geodin Analogues}

5,7-Dichloro-4,6' -dimethoxy-6-methyl-3,4' -dioxospiro [benzofuran-2(3H), $1^{\prime}$-[2,5]cyclohexadiene]-2'-carboxylic

Acid (4)

$40 \%$ aqueous tetra- $n$-butylammonium hydroxide $(45 \mu 1)$ was added to a solution of (+)-geodin $(12 \mathrm{mg}, 30 \mu \mathrm{mol})$ in THF $(0.2 \mathrm{ml})$, and stirred at $60^{\circ} \mathrm{C}$ for 10 minutes. After addition of $5 \% \mathrm{HCl}$, the mixture was extracted with ethyl acetate. The organic layer was dried over $\mathrm{Na}_{2} \mathrm{SO}_{4}$ and concentrated in vacuo. The residue was purified by silica gel TLC developed with $\mathrm{CHCl}_{3} / \mathrm{MeOH}(95: 5)$ containing $1 \%$ formic acid to yield 4 .

43\%; ESI MS $m / z 383(\mathrm{M}-\mathrm{H})^{-}$; ${ }^{1} \mathrm{H}$ NMR $(300 \mathrm{MHz}$, $\left.\mathrm{CD}_{3} \mathrm{OD}\right) \delta 6.96(1 \mathrm{H}, \mathrm{d}, J=1.2 \mathrm{~Hz}), 5.88(1 \mathrm{H}, \mathrm{d}, J=1.2 \mathrm{~Hz})$, $3.73(3 \mathrm{H}, \mathrm{s}), 2.54(3 \mathrm{H}, \mathrm{s})$.

Methyl 5,7-Dichloro-4,6'-dimethoxy-6-methyl-3,4'dioxospiro[benzofuran-2(3H), $1^{\prime}$-[2,5]cyclohexadiene]-2' carboxylate (5a)

$\mathrm{K}_{2} \mathrm{CO}_{3}(2 \mathrm{mg}, 14 \mu \mathrm{mol})$ and methyliodide $(3 \mu \mathrm{l}, 32 \mu \mathrm{mol})$ were added to a solution of ( \pm )-geodin $(4.5 \mathrm{mg}, 11.2 \mu \mathrm{mol})$ in DMF $(0.2 \mathrm{ml})$, and stirred for 5 hours at room 
temperature. After addition of water, the mixture was extracted with ethyl acetate. The organic layer was dried over $\mathrm{Na}_{2} \mathrm{SO}_{4}$, and concentrated in vacuo. The residue was purified by silica gel TLC developed with $\mathrm{CHCl}_{3}$ to yield 5a.

64\%; FAB MS $m / z 413(\mathrm{M}+\mathrm{H})^{+}$; HR-MS $m / z 413.0202$ $(\mathrm{M}+\mathrm{H})^{+}$calcd $\mathrm{C}_{18} \mathrm{H}_{15} \mathrm{O}_{7}^{35} \mathrm{Cl}_{2}(\Delta+0.7 \mathrm{mmu}) ;{ }^{1} \mathrm{H}$ NMR $(300$ $\left.\mathrm{MHz}, \mathrm{CDCl}_{3}\right) \delta 7.13(1 \mathrm{H}, \mathrm{d}, J=1.5 \mathrm{~Hz}), 5.81(1 \mathrm{H}, \mathrm{d}, J=1.5$ $\mathrm{Hz}), 4.12(3 \mathrm{H}, \mathrm{s}), 3.74(3 \mathrm{H}, \mathrm{s}), 3.70(3 \mathrm{H}, \mathrm{s}), 2.59(3 \mathrm{H}, \mathrm{s})$.

Methyl 4-Benzyloxy-5,7-dichloro-6' -methoxy-6-methyl-

3,4'-dioxospiro[benzofuran-2(3H), $1^{\prime}$-[2,5]-

cyclohexadiene]-2'-carboxylate (5b)

92\%; FAB MS $m / z 489(\mathrm{M}+\mathrm{H})^{+}$; HR-MS $m / z 489.0506$ $(\mathrm{M}+\mathrm{H})^{+}$calcd $\mathrm{C}_{24} \mathrm{H}_{19} \mathrm{O}_{7}^{35} \mathrm{Cl}_{2}(\Delta-0.2 \mathrm{mmu}) ;{ }^{1} \mathrm{H}$ NMR (300 $\left.\mathrm{MHz}, \mathrm{CDCl}_{3}\right) \delta 7.53(2 \mathrm{H}, \mathrm{br} \mathrm{d}, J=7.2 \mathrm{~Hz}), 7.34 \sim 7.40(3 \mathrm{H}$, m), $7.15(1 \mathrm{H}, \mathrm{d}, J=1.8 \mathrm{~Hz}), 5.82(1 \mathrm{H}, \mathrm{d}, J=1.8 \mathrm{~Hz}), 5.38$ $(1 \mathrm{H}, \mathrm{d}, J=11.1 \mathrm{~Hz}), 5.29(1 \mathrm{H}, \mathrm{d}, J=11.1 \mathrm{~Hz}), 3.74(3 \mathrm{H}, \mathrm{s})$, $3.68(3 \mathrm{H}, \mathrm{s}), 2.58(3 \mathrm{H}, \mathrm{s})$.

Methyl 4-(tert-Butoxycarbonylmethyloxy)-5,7-dichloro-6'methoxy-6-methyl-3,4'-dioxospiro[benzofuran-2(3H), 1'[2,5]cyclohexadiene]-2'-carboxylate (5c)

91\%; FAB MS $m / z 512(\mathrm{M}+\mathrm{H})^{+}$; HR-MS $m / z 512.0620$ $(\mathrm{M}+\mathrm{H})^{+}$calcd $\mathrm{C}_{23} \mathrm{H}_{22} \mathrm{O}_{9}^{35} \mathrm{Cl}_{2}(\Delta-2.1 \mathrm{mmu}) ;{ }^{1} \mathrm{H}$ NMR (300 $\left.\mathrm{MHz}, \mathrm{CDCl}_{3}\right) \delta 7.12(1 \mathrm{H}, \mathrm{d}, J=2.1 \mathrm{~Hz}), 5.79(1 \mathrm{H}, \mathrm{d}, J=2.1$ $\mathrm{Hz}), 5.02(1 \mathrm{H}, \mathrm{d}, J=15.9 \mathrm{~Hz}), 4.95(1 \mathrm{H}, \mathrm{d}, J=15.9 \mathrm{~Hz})$, $3.72(3 \mathrm{H}, \mathrm{s}), 3.67(3 \mathrm{H}, \mathrm{s}), 2.59(3 \mathrm{H}, \mathrm{s}), 1.44(9 \mathrm{H}, \mathrm{s})$.

Methyl 4-Carboxymethyloxy)-5,7-dichloro-6'-methoxy-6methyl-3,4'-dioxospiro[benzofuran-2(3H), $1^{\prime}$-[2,5]cyclohexadiene]-2'-carboxylate (5d)

TFA $(0.1 \mathrm{ml})$ was added to a solution of $\mathbf{5 c}(5 \mathrm{mg}, 9.7$ $\mu \mathrm{mol})$ in $\mathrm{CH}_{2} \mathrm{Cl}_{2}(0.5 \mathrm{ml})$, and stirred for 1 hour at room temperature. The reaction mixture was concentrated in vacuo to give carboxylic acid $\mathbf{5 d}$.

100\%; ESI MS $m / z 457(\mathrm{M}+\mathrm{H})^{+}$; HR-MS $m / z 457.0088$ $(\mathrm{M}+\mathrm{H})^{+}$calcd $\mathrm{C}_{19} \mathrm{H}_{15} \mathrm{O}_{9}^{35} \mathrm{Cl}_{2}(\Delta-1.1 \mathrm{mmu}) ;{ }^{1} \mathrm{H}$ NMR (300 $\left.\mathrm{MHz}, \mathrm{CDCl}_{3}\right) \delta 7.14(1 \mathrm{H}, \mathrm{d}, J=1.2 \mathrm{~Hz}), 5.83(1 \mathrm{H}, \mathrm{s}), 4.89$ $(2 \mathrm{H}, \mathrm{br} \mathrm{s}), 3.75(3 \mathrm{H}, \mathrm{s}), 3.70(3 \mathrm{H}, \mathrm{s}), 2.62(3 \mathrm{H}, \mathrm{s})$.

Methyl 3',5'-Dibromo-2',4,6'-trihydroxy-6-methoxy-4'methylbenzophenone-2-carboxylate (6)

$\mathrm{CaCO}_{3}(25 \mathrm{mg}, 0.25 \mathrm{mmol})$ and benzyltrimethylammonium tribromide $(95 \mathrm{mg}, 0.24 \mathrm{mmol})$ were added to a solution of sulochrin (40 mg, $0.12 \mathrm{mmol}$ ) in $\mathrm{CH}_{2} \mathrm{Cl}_{2} / \mathrm{MeOH}(1 \mathrm{ml})$, and stirred for 30 minutes at room temperature. Then $\mathrm{CH}_{2} \mathrm{Cl}_{2}$ was added into reaction mixture, and washed with $5 \% \mathrm{HCl}$. The organic layer was dried over $\mathrm{Na}_{2} \mathrm{SO}_{4}$, and concentrated in vacuo. The residue was purified by silica gel TLC developed with $\mathrm{CHCl}_{3} / \mathrm{MeOH}(95: 5)$ to give 6 .
63\%; ESI MS $m / z 487(\mathrm{M}-\mathrm{H})^{-} ;{ }^{1} \mathrm{H}$ NMR $(300 \mathrm{MHz}$ $\left.\mathrm{CDCl}_{3} / \mathrm{DMSO}_{-} d_{6}\right) \delta 6.93(1 \mathrm{H}, \mathrm{d} . J=1.5 \mathrm{~Hz}), 6.57(1 \mathrm{H}, \mathrm{d}$, $J=1.5 \mathrm{~Hz}), 3.63(3 \mathrm{H}, \mathrm{s}), 3.61(3 \mathrm{H}, \mathrm{s}), 2.52(3 \mathrm{H}, \mathrm{s})$.

Methyl 5,7-Dibromo-4-hydroxy-6'-methoxy-6-methyl$3,4^{\prime}$-dioxospiro[benzofuran-2(3H), $1^{\prime}$-[2,5]cyclohexadiene]2'-carboxylate (7a)

Compound $\mathbf{6}$ was converted to $7 \mathbf{a}$ by phenol oxidative coupling reaction with DDQ described above.

54\%; FAB MS $m / z 487(\mathrm{M}+\mathrm{H})^{+}$; HR-MS $m / z 486.9023$ $(\mathrm{M}+\mathrm{H})^{+}$calcd $\mathrm{C}_{17} \mathrm{H}_{13} \mathrm{O}_{7}^{79} \mathrm{Br}_{2}(\Delta-0.5 \mathrm{mmu}) ;{ }^{1} \mathrm{H}$ NMR (300 $\left.\mathrm{MHz}, \mathrm{CDCl}_{3}\right) \delta 7.15(1 \mathrm{H}, \mathrm{d}, J=1.5 \mathrm{~Hz}), 5.83(1 \mathrm{H}, \mathrm{d}, J=1.5$ $\mathrm{Hz}), 3.74(3 \mathrm{H}, \mathrm{s}), 3.70(3 \mathrm{H}, \mathrm{s}), 2.69(3 \mathrm{H}, \mathrm{s})$.

Methyl 4-Hydroxy-5,7-diiodo-6' -methoxy-6-methyl-3,4' dioxospiro[benzofuran-2(3H), $1^{\prime}$-[2,5]cyclohexadiene]-2' carboxylate (7b)

Iodine $(16 \mathrm{mg}, 63 \mu \mathrm{mol})$, potassium iodide $(11 \mathrm{mg}, 66$ $\mu \mathrm{mol})$ and sodium acetate $(5 \mathrm{mg}, 61 \mu \mathrm{mol})$ were added to a solution of sulochrin $(20 \mathrm{mg}, 60 \mu \mathrm{mol})$ in DMF $(1 \mathrm{ml})$. The reaction mixture was stirred for 14 hours at room temperature. Then ethyl acetate was added into reaction mixture, and washed with $5 \%$ sodium hydrogen sulfite. The organic layer was dried over $\mathrm{Na}_{2} \mathrm{SO}_{4}$ and concentrated in vacuo. The residue was purified by silica gel TLC developed with $\mathrm{CHCl}_{3} / \mathrm{MeOH}(96: 4)$ to give $7 \mathbf{b}$.

11\%; FAB MS $m / z 581(\mathrm{M}-\mathrm{H})^{-}$; HR-MS $m / z 580.8632$ $(\mathrm{M}-\mathrm{H})^{-}$calcd $\mathrm{C}_{17} \mathrm{H}_{11} \mathrm{O}_{7} \mathrm{I}_{2}(\Delta+3.7 \mathrm{mmu}) ;{ }^{1} \mathrm{H}$ NMR $(300$ MHz, DMSO- $\left.d_{6}\right) \delta 7.01(1 \mathrm{H}, \mathrm{d}, J=1.5 \mathrm{~Hz}), 6.02(1 \mathrm{H}, \mathrm{d}$, $J=1.5 \mathrm{~Hz}), 3.69(3 \mathrm{H}, \mathrm{s}), 3.64(3 \mathrm{H}, \mathrm{s}), 2.79(3 \mathrm{H}, \mathrm{s})$.

\section{Preparation of Rat Adipocytes}

Adipocytes were prepared from male Wistar rats (150 $200 \mathrm{~g})$. Epididymal fat pads $(6.0 \mathrm{~g})$ were cut into small pieces in the medium containing $\mathrm{NaCl}(130 \mathrm{mM}), \mathrm{KCl}$ (4.7 mM), $\mathrm{KH}_{2} \mathrm{PO}_{4}(1.2 \mathrm{mM}), \mathrm{MgSO}_{4}(1.2 \mathrm{mM}), \mathrm{CaCl}_{2}$ $(1 \mathrm{mM})$, HEPES $(25 \mathrm{mM})$ with $5 \%$ BSA $(\mathrm{pH} 7.6)(6 \mathrm{ml})$. After addition of type I collagenase (2.4\%) into the medium, these tissues were treated with the enzyme for 40 minutes to obtain isolated adipocytes. After removal of collagenase by washing and flotation with fresh medium, the new buffer consisting with $2 \%$ BSA was added to give the suspension of adipocytes $(45 \mathrm{ml})$.

\section{Glucose Uptake Activity}

Adipocytes pretreated with each compound at $37^{\circ} \mathrm{C}$ for 30 minutes were incubated with further addition of $2-\left[U^{14} \mathrm{C}\right]-$ deoxy-D-glucose $(0.5 \mu \mathrm{Ci})$ for 5 minutes. The glucose uptake was terminated by the addition of $10 \mu \mathrm{M}$ of cytochalasin $\mathrm{B}$ followed by extraction with dinonylphthalatev and centrifuging to obtain an oil layer for 
determination of radioactivity of $2-\left[U^{14} \mathrm{C}\right]$-deoxy-Dglucose in the adipocytes.

Acknowledgement We thank Reiko Yuji, Naoko Shimba, and Mina Nakamura for measurement of NMR and mass spectra.

\section{References}

1. Simpson IA, Cushman SW. Hormonal regulation of mammalian glucose transport. Annu Rev Biochem 55: 1059-1089 (1986), and references cited therein.

2. Marcus S. Antibacterial activities of geodin and erdin. Biochem J 41: 462-463 (1947)

3. Fujii I, Iijima H, Tsukita S, Ebizuka Y, Sankawa U. Purification and properties of dihydrogeodin oxidase from Aspergillus terreus. J Biochem 101: 11-18 (1987)

4. Kato T, Omori O, Iwasaki K, Inoue M. Synthetic studies on Sch 202596, an antagonist of the galanin receptor subtype GalR1: an efficient synthesis of (土)-geodin, the spirocoumaranone part of Sch 202596. Tetrahedron 58: 1289-1299 (2002)

5. Zhang B, Salituro G, Szalkowski D, Li Z, Zhang Y, Royo I, Viella D, Diez MT, Pelaez F, Ruby C, Kendall RL, Mao X, Griffin P, Galaycay J, Zierath JR, Heck JV, Smith RG, Mollar DE. Discovery of a small molecule insulin mimetic with antidiabetic activity in mice. Science 284: 974-977 (1999)

6. Okada T, Sakuma R, Fukui Y, Hazeki O, Ui M. Blockage of chemotactic peptide-induced stimulation of neutrophils by wortmannin as a result of selective inhibition of phosphatidylinositol 3-kinase. J Biol Chem 269: 3563-3567 (1994)

7. Okada T, Kawano Y, Sakakibara T, Hazeki O, Ui M. Essential role of phosphatidylinositol 3-kinase in insulininduced glucose transport and antilipolysis in rat adipocytes. J Biol Chem 269: 3568-3573 (1994)

8. Abdel-Magid AF, Cohen JH, Maryanoff CF, Shah RD, Villani FJ, Zhang F. Hydrolysis of polypeptide esters with tetrabutylammonium hydroxide. Tetrahedron Lett 39: 33913394 (1998) 